\title{
Development of Various Source-Based Learning Models (BeBAS) Character-Oriented Education in Science Learning in Junior High School of City of Makassar
}

\author{
Suaib Ramli ${ }^{1}$, Patta Bundu², Anshari ${ }^{3}$ \\ ${ }^{1}$ Department of Education, Universitas Negeri Makassar \\ Jln. Bonto Langkasa Kampus Gunung Sari Baru Program Pascasarjana, Makassar, Indonesia \\ Email: ramlisuaibunm [AT] gmail.com \\ ${ }^{2}$ Department of Education, Universitas Negeri Makassar \\ Jln. Bonto Langkasa Kampus Gunung Sari Baru Program Pascasarjana, Makassar, Indonesia \\ Email: bundu [AT] unm.ac.id \\ ${ }^{3}$ Department of Bahasa, Universitas Negeri Makassar \\ Jln. Bonto Langkasa Kampus Gunung Sari Baru Program Pascasarjana, Makassar, Indonesia \\ Email: anshari [AT] unm.ac.id
}

\begin{abstract}
The aim of this research was to collect empirical data on the need for integrating science learning at the junior high school level, to develop a multi-source-based learning model (BeBAS) in character education-oriented science learning that is valid for junior high school students, and to develop an education-oriented multi-source based learning model (BeBAS) practical and effective character in science learning for junior high school students. This project is classified as research and development (Research and Development) since it focuses on the investigation of goods in the context of a multi-source-based learning model (BeBAS) geared towards character education in science learning. The Four-D model was used in this study as the production model. This model's design process consists of four stages: describe, design, create, and disseminate. This study was carried out at SMP Negeri 1 Makassar. The result of this research will be a model book that includes: (1) the rationality of the multi-source-based learning model (BeBAS) oriented towards character education, and (2) the ideas that favor the multi-source based learning model (BeBAS) oriented towards character education. (3) guidelines for implementing a multi-source learning model based on character education (BeBAS), and (4) the components of the multi-source learning model (BeBAS) oriented towards character education and learning tools with a character education-oriented multi-source learning model (BeBAS) in the form of Student Book, Student Worksheet, Learning Implementation Plan that has gone through stages (1) expert validation, (2) revision based on validator assessments, suggestions.
\end{abstract}

Keywords--- learning based on various sources (BeBAS), character education

\section{INTRODUCTION}

Multi-source oriented learning (BeBAS) refers to a set of techniques that facilitate learner-centered learning in the sense of mass education by combining specially developed learning tools with digital media and technology [1]. In the information age, students are exposed to more information at any given time than ever before, necessitating the willingness of students to choose and use these channels for optimum learning purposes, all of which are completely digitalized, and learning materials are accessible online. Indeed, several book publishers began to view e-books, and we can do something with tablets, tabs and laptops. Even the school sector is beginning to adopt an e-learning system, which eliminates the need for teachers and students to meet face to face. Face-to-face communication is being replaced by advanced technologies. This e-learning approach is unquestionably beneficial because it is a means of adaptation to changing times, such as information sharing.

However, we should not refuse to influence, among others: the detrimental effect of being totally online can affect individual characters created from a small one, such as authenticity, checked when blogging and various reality when using social media, accountability. On the other hand, many learning opportunities are gained from the digital environment. decreases as social media time is forgotten such the time runs out to complete their principal activities, such as educating students and adults working, caring and appreciation decreases, as they are adequately portrayed by social networks without physical interaction with the group. 
It is why character education should be provided for Lickona-based pupils, namely, to ensure their personality is healthy, to increase academic performance, to create positive character, to appreciate other people in society, to welcome behaviour, and to teach cultural values [2]. It is in accordance with Law 20 of 2003 on the National Education System where it has been stressed that the role of national education is to develop capacity and shape a dignified national and civilisation to enhance the life of the nation in order to develop the potential of students to become morally believing and fearful God, the Almighty.

The core of education in Indonesia in the field of education is value education, in particular the education of noble values derived from Indonesian culture in order to cultivate the identity of the younger generation in an age of globalization. Implementing the importance of character education in schooling involves not being a popular teaching material in the context of cultural values and national character, those principles shall not be used as a theme, as in teaching a philosophy, theory, practice, or reality as in the subject. Teachers may use subject matter as content or advertising to create cultural values and national character in order to develop those values. Teachers must also not alter current topics but rather transform them into cultural ideals and national character.

The results of preliminary observations on science teachers at SMP Negeri 1 Makassar were obtained (1) the teacher did not fully understand how to integrate character education into learning according to the demands of the 2013 curriculum, (2) the use of online learning resources at SMP Negeri 1 Makassar was increasing which could affect directly character education of students, (3) in addition there is no learning model based on learning resources oriented to character education to increase the value of character education of students in science learning.

The author's opinion is supported by the data that the value of every aspect of character education in science learning of class VIII students of SMP Negeri 1 Makassar in the last two years is in the sufficient category or has not met the required category, namely the minimum good category or the range of values 75.0 - 79.9 based on Permendikbud Number 43 of 2019. The value of character education for students in the 2017/2018 school year has a value of 73.00 and the $2018 / 2019$ school year is only 74.00. From these results then grouped so that the data for the 2017/2018 school year amounted to 396 people consisting of 11 classes. The scores of 80.00 and above (very good category) were only 78 people or 19.70 percent and the values between 79.9 - 75.00 (good category) 81 people or 20.45 percent and the values $74.9-70$ (enough category) were 185 people or 46.71 percent and a value below than 70 (under category) as many as 52 people or 13.13 percent. Whereas in the 2018/2019 school year there were 396 people who also consisted of 11 classes, scores of 80.00 and above (very good category) were only 70 people or 17.68 percent and values between 79.9 - 75.00 (good category) 47 people or 11.88 percent and a value of 74.9 - 70 (enough category) as many as 190 people or 47.98 percent and a value below than 70 (under category) as many as 89 people or 22.47 percent. (Source: Data on Curriculum Affairs at SMPN 1 Makassar, 2019).

Based on the initial conditions above, it is required to develop a learning model based on learning resources and oriented to character education in science learning which aims to help science teachers to increase the value of character education for students in the learning process effectively at SMP Negeri 1 Makassar.

\section{RESEARCH METHODS}

This research is categorized as research and development (Research and Development), with the main reason that this development research focuses on the study of products in the form of models and tools and instruments based on learning resources and oriented to character education. The development model used in this research is the Four-D model. Where the design of this model includes four stages, namely define, design, develop and disseminate.

This research was conducted at SMP Negeri 1 Makassar. The subject of the trial was divided into two stages, namely: 1) The development stage was class VIII students of SMP Negeri 1 Makassar; 2) The dissemination stage is a science subject teacher at SMP Negeri 1 Makassar and a science subject teacher in Makassar City who are members of the IPA MGMP forum throughout Makassar City. In this study, there were 3 data collection techniques used, namely: 1) the model validity assessment sheet, namely the learning device validity sheet, the instrument validity sheet used; 2) the observation sheet, namely the model needs observation sheet, the model practicality observation sheet and the model effectiveness observation sheet; 3 ) a questionnaire, namely a student response questionnaire. The data analysis techniques used in this study are as follows: (1) data analysis for the validity of the model; (2) data analysis model practicality; (3) data analysis on the effectiveness of the model.

\section{RESULTS AND DISCUSSION}

Assessment of research instruments is the initial stage that is carried out when learning in class is carried out in accordance with predetermined subjects consisting of 4 (four) meetings.

Based on the results of the analysis using the Gregory test, the values for the research instrument that will be used are 
obtained as presented in table 1 as follows:

Table 1. Recap of the Results of the Research Instrument Validation Analysis

\begin{tabular}{ccccc}
\hline \multirow{2}{*}{ Instrument Assessment } & \multicolumn{2}{c}{ Value } & Categorize \\
\cline { 2 - 5 } Model Development Needs & Validity & Coefficient (\%) & Fulfill \\
\hline Learning Model Assessment & 3,93 & 100 & Very Valid & Fulfill \\
\hline Model Implementation Instruments & 3,95 & 100 & Very Valid & Fulfill \\
\hline Model management assessment & 4,00 & 100 & Very Valid & Fulfill \\
\hline Observation of Character Behavior & 4,00 & 100 & Very Valid & Fulfill \\
\hline $\begin{array}{c}\text { Student Activities } \\
\text { Student Response Questionnaire }\end{array}$ & 3,70 & 100 & Very Valid & Fulfill \\
\hline Implementation of Learning & 3,95 & 100 & Very Valid & Fulfill \\
\hline Student Book Assessment & 3,81 & 90 & Very Valid & Fulfill \\
\hline Student Worksheet Assessment & 3,98 & 95 & Very Valid & Fulfill \\
\hline
\end{tabular}

These results indicate that the research instrument is in the category $3.5 \leq 4.0$ (very valid). As for the internal consistency coefficient value of KKI> 0.75, it is said that the instrument fulfills the content validity, so it is feasible to be used. Based on the data from the results of the assessment by two validators, it was found that the components of the model and the multi-source based learning model (BeBAS) oriented towards character education had the mean value of the validator for the presentation assessment tool which was generally in the very valid category. This means that the model developed has met the validity criteria.

Activities carried out after the multi-source based learning model (BeBAS) oriented towards character education along with the tools and instruments were declared valid, namely (1) testing the model, (2) analyzing the test results, and (3) making revisions. based on the results of the analysis. The trial of a character education-oriented learning model (BeBAS) was conducted 2 times, until a model that met the criteria was practical and effective. Trial I was carried out in class VIII1 of SMP Negeri 1 Makassar as many as 25 students as trial subjects and trial II was carried out in class VIII-2 of SMP Negeri 1 Makassar totaling 25 students as trial subjects. The material being tested is the concept of an optical instrument. The two classes are assumed to be homogeneous because of the placement of students in these classes since the class distribution was carried out randomly.

The practicality of the learning model can be seen through the implementation of the learning model and the ability of the teacher to manage learning. In the first trial the implementation of the learning model had an average of 1.83 (fully implemented category) and the teacher's ability to manage learning had an average of 3.50 (good category). In the second trial the implementation of the learning model had an average of 1.83 (fully implemented category) and the teacher's ability to manage learning had an average of 3.88 (good category). Because the indicators of the implementation of the multisource based learning model (BeBAS) oriented to character education in learning have been fully implemented and the teacher's ability to manage learning is in the high category, the model developed is called practical.

Learning model based on various sources (BeBAS) oriented to effective character education is obtained through indicators of achieving the ideal time for student activities to be fulfilled and the positive response of students to the multisource based learning model (BeBAS) oriented to character education shows a positive response.

The value of character education that is measured in the learning process in trials I and II is character education of responsibility, discipline, cooperation, and careful work. The following is presented in table 1 which is a recapitulation of the measured value of character education at each meeting. 
Table 2. The results of the analysis of the character education values of students per meeting of the various sources-based learning model (BeBAS) oriented towards character education in trials I and II

\begin{tabular}{|c|c|c|c|c|c|c|c|c|c|c|c|c|}
\hline \multirow{3}{*}{$\begin{array}{c}\text { Value of } \\
\text { Character } \\
\text { Education }\end{array}$} & \multicolumn{5}{|c|}{ TRIAL I } & \multirow{3}{*}{$\begin{array}{c}\text { Cate } \\
\text { goriz } \\
e \\
\end{array}$} & \multirow{2}{*}{\multicolumn{5}{|c|}{$\begin{array}{l}\text { TRIAL II } \\
\text { Meeting- }\end{array}$}} & \multirow{3}{*}{$\begin{array}{c}\text { Categor } \\
\text { ize }\end{array}$} \\
\hline & \multicolumn{5}{|c|}{ Meeting- } & & & & & & & \\
\hline & $I$ & $I I$ & III & $I V$ & Mean & & $I$ & $I I$ & III & $I V$ & Mean & \\
\hline $\begin{array}{c}\text { Commitme } \\
n t\end{array}$ & 50 & 53 & 55 & 55 & 53,3 & $\begin{array}{l}\text { Very } \\
\text { Low }\end{array}$ & 75 & 76 & 78 & 82 & 77,8 & Good \\
\hline Discipline & 54 & 53 & 55 & 56 & 54,5 & $\begin{array}{l}\text { Very } \\
\text { Low }\end{array}$ & 75 & 74 & 76 & 83 & 77,0 & Good \\
\hline $\begin{array}{c}\text { Cooperatio } \\
n\end{array}$ & 53 & 56 & 57 & 57 & 55,8 & $\begin{array}{l}\text { Very } \\
\text { Low }\end{array}$ & 76 & 77 & 79 & 82 & 78,5 & Good \\
\hline $\begin{array}{c}\text { Work } \\
\text { Thoroughl } \\
y\end{array}$ & 51 & 53 & 55 & 56 & 53,8 & $\begin{array}{l}\text { Very } \\
\text { Low }\end{array}$ & 76 & 77 & 79 & 82 & 78,5 & Good \\
\hline
\end{tabular}

Table 2 above shows that in the first trial the average value of every aspect of character education observed was at $\leq$ 60 intervals which were included in the very poor category (did not meet the minimum required criteria well). Whereas in the second trial it showed that the average value of every aspect of character education that was observed was generally in the interval 75 - 79.9 which was included in the good category or met the minimum required criteria. This shows an increase in the character education value of students from trial I to trial II.

For the multi-source-based learning model (BeBAS) oriented to character education, it can be said that it is effective and must meet 3 requirements, namely: (1) the achievement of the ideal time for student activities is fulfilled; (2) Most of the students gave a positive response; (3) there is an increase in the character education value of students (at least it is in the good category). The results of the second trial showed that the achievement of the ideal time for the activities of students and the responses of students and the increase in the value of character education of students (at least in the good category) were all met. Therefore, the learning model based on various sources (BeBAS) oriented to character education after going through the second trial phase is declared to have met the effectiveness requirements.

\section{CONCLUSION}

Science learning at the junior high school level, especially at SMP Negeri 1 Makassar, uses online learning resources whose use continues to increase and has a direct impact on the character education of students.

Learning model based on various sources (BeBAS) oriented to character education supported by learning tools and developed through the stages of defining, designing, developing, disseminating and supported by expert validation results so that this model called valid.

The multi-source-based learning model (BeBAS) is oriented towards practical and effective character education:

1. Learning-based learning model based on various sources (BeBAS) oriented to practical character education is obtained through indicators of the implementation of learning model based on various sources (BeBAS) oriented to character education in learning has been fully implemented and the ability of teachers to manage learning based on various sources (BeBAS) oriented to character education is in either category.

2. Learning-based learning model based on various sources (BeBAS) oriented to effective character education is obtained through the achievement of indicators for the ideal time of student activities that have been fulfilled and the positive response of students to the multi-source based learning model (BeBAS) oriented to character education shows a positive response and increases the value of character education learners.

\section{REFERENCES}

[1] Astra IM, Wahidah RS. Peningkatan Keterampilan Proses Sains Siswa Melalui Model Guided Discovery Learning Kelas XI MIPA pada Materi Suhu dan Kalor. Jurnal Penelitian \& Pengembangan Pendidikan Fisika. 2017 Dec 30;3(2):181-90.

[2] Dalmeri D. Pendidikan Untuk Pengembangan Karakter (Telaah terhadap Gagasan Thomas Lickona dalam Educating For Character). Al-Ulum. 2014 Jun 1;14(1):269-88. 